\title{
All American Girls: \\ Women Pin-Up Artists of the First Half of the Twentieth Century
}

While male illustrators including Alberto Vargas (1896-1982), George Petty (1894-1975), and Gil Elvgren (1914-80) are synonymous with the field of early-twentieth-century pin-up art, there were, in fact, several women who also succeeded in the genre. Pearl Frush (1907-86), Zoë Mozert (1907-93), and Joyce Ballantyne (1918-2006) are three such women; each of whom established herself as a successful pin-up artist during the early to mid-twentieth century. While the critical study of twentieth-century pin-art is still a burgeoning field, most of the work undertaken thus far has focused on the origin of the genre and the work of its predominant artists who have, inevitably, been men. Women pin-up artists have been largely overlooked, which is neither surprising nor necessarily intentional. While illustration had become an acceptable means of employment for women by the late-nineteenth century, the pin-up genre of illustration was male dominated. In a manifestly sexual genre, it is not surprising that women artists would be outnumbered by their male contemporaries, as powerful middle-class gender ideologies permeated American culture well into the mid-twentieth century. These ideologies prescribed notions of how to live and present oneself — defining what it meant to be, or not be, respectable. ${ }^{1}$ One of the most powerful systems of thought was the domestic ideology, which held that a woman's moral and spiritual presence was key to not only a successful home but also to the strength of a nation (Kessler-Harris 49). Thus, the idea that a woman could be both the subject and creator of what was presumed to be heterosexual male fantasies conflicted with earlytwentieth-century American society's understanding of the so-called proper roles for respectable 
women. As such, it is not surprising that the field of pin-up art became male dominated. The intended audience of such illustrations was presumed to be male and choosing to enter such a highly sexualized field would have run counter to popular, socially prescribed gender norms for women. As a result, women pin-up artists, as compared to men, were few and far between. However, women were not completely absent from the male dominated pin-up world, just as they were not absent from other so-called masculine fields of art, such as mural painting. ${ }^{2}$ Three of the most successful women pin-up artists of the first half of the twentieth century deserve greater attention, in part because they used a variety of skillful means to enter and succeed in what was, undoubtedly, a highly sexualized and contested field of art. Pearl Frush, Zoë Mozert, and Joyce Ballantyne utilized their skills as illustrators to push the boundaries of the field of illustration for women. For them and other women pin-up artist of the twentieth century, the pinup offered a unique opportunity to assert agency over a supposedly masculine genre and to help redefine the parameters of women's professional pursuits.

\section{Women as Illustrators}

Beginning in the 1880 s, the nineteenth century saw a major expansion in the publication and popularization of magazines and serial periodicals, most of which were aimed at middle-class women consumers. Periodicals became one of the primary mediums of cultural circulation of the era with hundreds of periodicals in print at any given time (Shuttleworth et al. 57). In America, the period was deemed the Golden Age of Illustration. It lasted from approximately the 1880s to the 1920s and was the result of advances in print technology, including the development of the halftone plate and the introduction of high speed presses (Goodman 13). These new developments directly affected the print industry's ability to mass produce printed materials such 
as periodicals and books. From 1885 to 1905 , around 11,000 periodicals and magazines were published in the United States, with women constituting the vast majority of subscribersapproximately 88 percent (Prieto 160). Because these materials could now be produced and distributed in large quantities, there was a major decrease in the consumer's cost, making items such as magazines more affordable to the ever-increasing middle-class society of the latenineteenth century. ${ }^{3}$ As art historian Helen Goodman has stated, the new array of weekly and monthly periodicals were a popular form of entertainment much like television and the movies are for today's society and, as a result of the speed at which these materials were being consumed, the field of illustration flourished as never before (13). Countless illustrators were needed in order to keep up with the demand for more publications and because women were the primary consumers of this expanding market, magazine and children's book producers specifically sought out women artists to produce illustrations that they believed would appeal to their female consumers (Prieto 160).

The acceptance of women as professional illustrators during the late-nineteenth century stemmed, amongst other reasons, from the fact that they were presumed to have a better understanding of what women consumers wanted, and would thus be inherently suited to illustrating women's periodicals and children's books. This philosophy was based on the widely shared assumption that all women possessed similar sensibilities as a direct result of being biologically female. Additionally, women were sought as illustrators for children's books because of the assumption that women knew more about children than men and would, therefore, be better equipped to create illustrations for children (Callen 200). According to late-Victorian art critic Regina Armstrong, author of "Representative American Women Illustrators: The Child Interpreters" (1900), many publishers believed that the qualities of pictorial interpretation were 
"distinctly the faculty of a woman's delicacy and insight to portray" (418). Even prior to the latenineteenth-century boom in the print industry, however, women were believed to be particularly suited for jobs in the field of illustration. In The Employments for Women (1863), women were praised for their "neatness" and "patience," characteristics that it was claimed "fit them admirably" for the work of painting plates for books (Penny 88). Victorian women were believed to have a natural disposition for illustration because of their supposed delicate, detailed, and patient feminine demeanours, a belief that was confirmed by Armstrong who, in a subsequent article, "Representative American Women Illustrators: The Character Workers," stated that: The personal point of view is peculiarly feminine, the personal note as well; so it naturally follows that in the interpretation of character, the woman illustrator finds a field especially fitted to her temperamental equipment. The genre [illustration] attracts her, the conventional is understood by her, and in turn the poetic, the homely, and the picturesque, each presents its artistic atmosphere to her with appreciable congruity. (43)

While steeped in gendered rhetoric, paradoxically, these values and beliefs opened the door to professionalization for late-nineteenth-century women, as illustration came to serve as a respectable means of employment for women who either wanted or found it necessary to support themselves.

While many women artists did indeed have highly successful professional careers as illustrators, being biologically female did not predispose them to success. Rather, their ability to identify, understand, and render popular narratives and social notions into a visual form led them to have prosperous careers. American illustrator Jessie Willcox Smith (1863-1935), for example, was one of the most prominent and celebrated children's book illustrators during the late- 
nineteenth and early-twentieth centuries. Contrary to traditional mores, however, Smith never married, never had any children, and, in fact, lived the majority of her life with a female companion. Thus, the supposition that Smith, as a woman, would have an inherent understanding of children, does not align with the life she chose to lead. Smith's success, therefore, reflects her aptitude for identifying and understanding models of childhood that would prove commercially successful rather than reflecting any supposed inherent connection to children.

The cultural legitimacy of women working as professional illustrators carried over to the twentieth century, with some pushing beyond women's magazines and children's books to, ultimately, choosing pin-up work. While women illustrators of the early- to mid-twentieth century were not necessarily viewed as inherently qualified to produce pin-up art in the same way that their predecessors were viewed as a "natural" fit for women's periodicals and children's books, like Jessie Willcox Smith, they used their astute understanding of popular social notions and gender ideologies to create idealized images of women that rivaled if not surpassed those of their many male contemporaries.

\section{Defining the Pin-Up}

As far back as 1946, film critic André Bazin sought to define what constitutes a pin-up in his article "Entomology of the Pin-Up Girl." He stated, "First, let us not confuse the pin-up girl with the pornographic or erotic imagery that dates from the dark backward and abysm of time. The pin-up girl is a specific erotic phenomenon, both as to form and function" (158). It is interesting to note that the women portrayed in pin-up art are referred to as "pin-up girls" rather than women. In a context such as this, these terms become loaded with meaning. Bazin goes on to describe the pin-up as an "American Venus" who is a "tall, vigorous girl" and continues, "with 
her narrow hips, the pin-up girl does not evoke motherhood" (158). Perhaps then the choice of "girl" is tied to an ideal of maidenhood. The females portrayed by pin-up artists are identified as "girls" not because of being minors with regard to age, but rather because of their status as unmarried women - a status that is in turn tied to an ideal of virginity. While the females portrayed by popular pin-up artists, including Alberto Vargas, were indeed meant to represent adult women, the connotation of "girl" lends to a perceived innocence-one that was ripe for the consumer's taking and arguably added to their appeal.

Art historian Maria Elena Buszek’s extensive study, Pin-Up Grrls (2006), traces the roots of the pin-up as far back as the fifteenth century, but she concludes that it was not until the Industrial Revolution and the explosion of mass-reproductive print technology, as well as the rise of the middle class, that a "true" pin-up genre began to develop (08-09). In addition to Buszek's critical study, this development can also be traced through the work of historian Joanne Meyerowitz, who, in her pivotal article "Women, Cheesecake, and Borderline Material" (1996), explains that "girlie calendars" emerged as a popular commodity during the 1910s followed by “girlie magazines" featuring erotic pictures of nude and semi-nude women, which continued to flourish well after the close of World War I (12). Having gained momentum in the previous decades, pin-up art as a genre earned its name and soared in popularity during World War II as US soldiers increasingly began pinning images of women from either magazines or other printed items onto their barrack walls, cockpits, and elsewhere (Hess 223). For the purposes of this article, the term "pin-up" refers to the genre of illustration made popular during the 1940s depicting youthful women, often scantily clad, who appeared in both calendars and men's magazines. 
In his essay "Pinup and Icon" (1972), art historian Thomas Hess surmised that by the 1940s, the "pin-up girl" had reached canonical form. While based upon a live model, the pin-up quickly became "a man-made object" (227). Illustrators transformed real women into sexualized types, often eliminating personal details to create a more generalized feminine form. The pin-up came to be defined largely as a "healthy, American, cheerleader type-buttoned-nose, wideeyed, long-legged, ample hips and breasts, and above all with open, friendly smile that discloses perfect, even, white teeth" (227). Far from a novelty, this transformation of woman into an idealized form is a continuation of a motif deeply rooted in the history of art. ${ }^{4}$ Having been revived and reimagined an infinite number of times, the ideological rendition of woman into an early-twentieth-century American pin-up is but one instance in a seemingly unending cycle of idealization and exploitation. As Joanne Meyerowitz has proven, however, the commercialization of erotic images that proliferated in the twentieth century found "women join[ing] men as voyeuristic observers of the female form, and not just in museums and galleries" (12). As women entered the workforce in unparalleled numbers in the first half of the twentieth century, they also became participants in a consumer culture in which they themselves were a commodity. This is particularly fascinating when one considers the field of pin-up art and women working as pin-up artists. Women pin-up artists became active purveyors of a sexual ideal in which they, as women, were also the objects of consumption - theoretically and, in the case of those artists who used themselves as models, literally.

\section{Pearl Frush (1907-86)}

Pearl Frush first enrolled in art classes in New Orleans, followed by training in Philadelphia, New York, and finally at the Art Institute of Chicago. In the early 1940s, while living in 
Chicago, Frush opened her first studio. She took on freelance jobs while also working for the studio of Sundblom, Johnson, and White, followed by a post at Gerlach-Barklow Calendar Company. Thanks to a succession of highly popular series, by 1943 she had established herself as one of Gerlach-Barklow's most important artists (Martignette 242). According to Mark Gabor, author of one of the earliest surveys of pin-up art, up to the 1940s the calendar industry operated predominantly on a wholesale basis for the purposes of advertising. Pin-ups were generally used to ornament calendars that would later be imprinted in order to market a business. Most calendar publishers produced what were called "stock" calendars that, upon commission, could be imprinted with a specific business's logo and relevant information. Companies such as banks, garages, insurance companies, and so on would order these types of calendars, though not necessarily always featuring pin-ups, to be produced with their information, which could then be handed out to clients as gifts or as promotional items. By the mid-1940s, however, the calendar industry experienced a shift. As a result of the growing popularity of calendars featuring pin-ups, publishers increasingly began to produce pin-up calendars exclusively for the retail market. Gabor states that "art work," by which he means painting and/or drawing, rather than photography was sought by calendar companies because it was considered to be more "appealing" and "timeless" (177). The demand for original artwork fueled the industry for illustrators. In 1947, with continued success, Frush's Aquatour series, featuring pin-ups in aquatic settings, broke all sales records. By the mid-1950s, famed calendar producer Brown \& Bigelow, one of the most prosperous calendar companies in America, sought Frush to produce works on their behalf-solidifying her status as one of the most successful pin-up artists of the period. 
Pearl Frush worked primarily in watercolor or gouache on illustration board with many of her originals measuring approximately 20 x 15 inches. Some of her pieces are signed "Mann," which is the name she took upon her third, and final, marriage (Martignette 242). ${ }^{5}$ Her work demonstrates a devotion to crisp detail while balancing the demand for an idealized female form. The women Frush created were not overly sexualized as compared to many other pin-up artists' work. Instead, she strove to create a glamorized version of the "girl next door." This treatment supports Thomas Hess's assessment that the pin-up "gave visual authenticity" to the image of a “docile, manipulatable godlet” (232). For example, Frush's pin-up entitled Always Ready (Figure 1) from 1945, depicts a youthful woman sweeping the floor - presumably keeping house and fulfilling her culturally accepted role as housewife. She is shown engaged in an activity that would in any other illustration be innocuous, but her lack of clothing and high heeled shoes immediately transforms this household chore into a fantasy. Frush's pin-up is seductive, both in title and depiction-Always Ready serving as a double entendre, a literal interpretation confirming the woman's ability to serve as a successful homemaker while simultaneously suggesting her sexual proclivity. Her apron serves as her only form of clothing, largely concealing her torso while giving the viewers full purview of her legs. Frush has positioned the figure in such a way that, at first glance, it would seem that she is leaning slightly forward in an effort to sweep the floor. This movement, however, also highlights the woman's décolleté and delineates her left leg, giving the viewer a glimpse of her behind. Thus, the viewer knows for certain that she is indeed otherwise nude. The woman's perfectly manicured red fingernails, open toed heels, and ruby red lips are the finishing touches on an already tantalizing, albeit unrealistic, vision of femininity. 
In her excellent article “The Way to a Man’s Heart: Gender Roles, Domestic Ideology, and Cookbooks in the 1950s," historian Jessamyn Neuhaus uses cookbooks as a means of exploring the complexities surrounding women's roles in the post-World War II era. She suggests that highly circulated mass-produced material, such as cookbooks, served as instructional texts and were part of a larger normative discourse regarding gender roles. The same can be said of pin-ups, which were also highly circulated mass-produced cultural artifacts. While pin-ups were not instructional manuals per se, certainly not in the same literal way as cookbooks, they were visual renditions of a culturally prescribed feminine ideal—an ideal disseminated through a variety of forms of popular and material culture that permeated the postwar era. Pin-ups not only instructed and shaped men's idea of the ideal woman, both in form and role, but the glamorized pin-up also long captured the imagination of American women who had been faced with these idealizations throughout the war years. ${ }^{6}$ Thus, the pin-up served as a prescriptive visualization of an ideal for both men and women alike. An ideal that was physically realized and circulated through various forms of popular culture in the postwar era.

Although Neuhaus's study is focused on cookbooks — prescriptive texts—she points out that the historical investigation of prescriptive literature only attests to the ways in which women were instructed to behave. Such texts do not reveal the ways in which women actually behaved (530). Rather, these texts speak to the pressures women encountered with regard to defining their lives exclusively as wives and mothers. Indeed, postwar rhetoric frequently combatted women's war-time employment by reiterating that a woman's place was in the kitchen and thus the home (532). Such discourses substantiate the notion that even while the lives of middle-class women were greatly changed during wartime America, the ideal of womanhood and the conception of a domestic ideology still pervaded. Cookbooks, pin-ups, and other facets of American popular 
culture fueled an insatiable postwar consumerism that longed to make these ideals real. Pin-ups, such as Pearl Frush's Always Ready, served as cultural representations of an idealized woman in both form and in function. While overtly sexualized, the bright smile of the woman depicted leads the viewer to believe that she is wholly satisfied in her traditional role as housewife. A role that, paradoxically, women pin-up artists, Pearl Frush included, largely contradicted through their professional pursuits.

\section{Zoë Mozert (1907-93)}

Zoë Mozert, born Alice Adelaide Moser, entered the Philadelphia School of Industrial Art in 1925, studying under American artist and illustrator Thornton Oakley (1881-1953). She modelled for art classes at the nearby Women's School of Design in order to pay her tuition. Mozert, probably the most successful woman pin-up artist of the early-twentieth century, had great commercial success. She moved to New York in 1932 and within four years painted more than four hundred covers for movie magazines, as well as covers for American Weekly. Her celebrity was such that along with famed pin-up artist George Petty (1894-1975) and illustrator James Montgomery Flagg (1877-1960), best known for his Uncle Sam recruitment poster, Mozert served as a judge at the 1938 Miss America Beauty Pageant. This was not, however, Mozert's first or last time serving as a judge for a beauty contest. In March 1938, the Chicago Daily Tribune reported that Mozert had been charged with selecting the winner of an "ideal model" contest ("Model's Favorite" 4). Nearly ten years later, on March 30, 1947, the Los Angeles Times reported that she once again served as a judge, this time along with fellow pin-up artist Earl Moran (1893-1984), to select a queen for a California festival ("Flower Festival Queen” 16). Illustrators, particularly pin-up artists, were regularly sought to serve as arbiters of 
beauty for both local and national contests. Understanding popular models of American beauty was key to the industry, and the more popular the work of a particular pin-up artist became, the more they were perceived to be an authority on beauty.

By 1941, Brown \& Bigelow had signed Mozert to an exclusive calendar contract. Her popularity was bolstered even further, however, when she was commissioned to create a movie poster for Howard Hughes's 1943 film, The Outlaw, featuring Jane Russell. Soon after, in 1946, Mozert had become one of the "Big Four" at Brown \& Bigelow, along with her contemporaries Rolf Armstrong (1889-1960), Earl Moran, and Gil Elvgren. Her works became so popular that the company had standing orders for her calendars every time a new one was published from many of their largest accounts (Martignette 304).

Mozert's celebrity continued to be fostered on a national level as she was featured repeatedly in major newspapers. ${ }^{7}$ On February 26, 1945, Mozert was profiled in the Los Angeles Times, page A1, in an article titled "Calendar Artist Mozert Uses Herself as Model." The article included a photograph of Mozert (Figure 2) standing between a mirror and an easel, as well as a completed pin-up. In the photograph, captioned "Pose with a Purpose," Mozert demonstrates how she would position herself in front of a mirror in order to serve as her own model. She is dressed in the same bathing suit and heels as the woman in the painting and even stands in the same position facing the mirror. This enables the reader to see Mozert's reflection, which, in dress and position, perfectly parallels the completed pin-up to her left.

The article opens, "It's bad enough to have a heretofore male-dominated field, the drawing of luscious lassies as calendar illustrations, successfully invaded by a gal, but when the gal actually looks like a calendar herself —well, maybe it's not so bad, after all.” Setting aside lascivious comments like "luscious lassies," the author's statement that pin-up art was, until this 
point, a male-dominated field is significant as it speaks to the boundaries that Mozert both challenged and redefined through her success. The article concludes by identifying Mozert as one of the "Big Three" in "calendar and magazine illustration," rather than solely within the field of pin-up art. She is cited along with famed American illustrators Norman Rockwell (18941978) and Bradshaw Crandall (1896-1966) as one of the most influential illustrators of the time, which not only puts her at the forefront of pin-up art but also positions her as a leader within the field of American illustration more generally during the first half of the twentieth century (“Calendar Artist Mozert" A1).

Mozert preferred models who were five feet three or four inches tall. She felt that "the big ones have too many joints" (“Calendar Artist Mozert” A1). Mozert's pin-ups range in stylistic form from fitting the topos that would later be defined by Thomas Hess to highly sexualized nudes. Her work entitled A Run on Sugar (Figure 3) from 1948, categorically fits within the former. While the woman depicted bears a rather striking resemblance to Mozert (she did, in fact, use herself as a model), it is uncertain whether she posed for this instance. The title is a pun that aptly describes the scene in which the woman's nylons have run while simultaneously conveying a sexual overtone. The woman's upward gaze, coupled with the halo of light highlighting the tips of her toes on her left foot, serves to draw the viewer's eye to the run in her stocking. Following the run down the woman's elongated leg allows the viewer's gaze to trace the woman's body as one's eyes "run" across her partially clothed form. The purple flowers topping her golden hair serve as a counterbalance to the vibrant purple high-heeled shoe on her right foot, which is also topped with a decorative floral form. These vivid points of color along with the halo effect around the top of her left foot help to focus the viewer's gaze - almost 
restricting it and forcing the eye to continuously trace the features of her form as the viewer's eyes "run" from point to point.

\section{Joyce Ballantyne (1918-2006)}

Born in Nebraska just after World War I, Joyce Ballantyne grew up with a love of drawingmaking and selling paper dolls for a dollar each during the Depression. In an interview conducted in 2004, she stated that growing up she had regularly entered art contests and had even won a scholarship to Disney's School for Animation in California. She explained, however, that the scholarship was rescinded after a phone call during which her young teenage voice gave away her sex and thus gender. According to Ballantyne, up to this point it had, evidently, been unclear to the Disney representatives that she was a woman. She stated that she was informed by the individual on the phone that women ultimately gave up their careers for marriage and children, and men were thus more promising candidates for the scholarships. In the 2004 interview, Ballantyne stated that it was "not the last time I heard that." This experience, however, did not dissuade Ballantyne, who subsequently undertook two years at the University of Nebraska and another two at the Academy of Art in Chicago (Klinkenberg).

Ballantyne started her artistic career illustrating dictionaries, creating maps for Rand McNally, and painting murals for movie theaters and department stores. She spent more than ten years working for the Stevens/Gross studio, where she became part of a tightknit group of artists that included her former teacher at the Academy of Art, famed pin-up artist Gil Elvgren. With the onslaught of World War II and the draft, Ballantyne, like many women, found new opportunities in wartime America. Elvgren recommended Ballantyne to Brown \& Bigelow, and 
by 1945 she was heralded by the company as "the brightest young star on the horizon of illustrative art” (Martignette 100).

Like fellow pin-up artist Zoë Mozert, Ballantyne often relied on herself as a model. Ballantyne's daughter, Cheri Brand Irwin, stated in an interview that her mother used photographs for many of her commissions. Irwin explained, "When she did pin ups in the '40s she would put herself in a position that she wanted the models in and if she didn't have a model she'd get in the position and use that to paint from." Irwin elaborated, however, that while her mother used herself as a model, it was only for the purposes of attaining the correct position. Once Ballantyne had achieved the desired pose, she would then paint a fictitious woman within that pose-creating and molding a commercially successful model of femininity (Irwin).

Women pin-up artists using themselves as models resulted in an interesting paradigm. In drawing upon themselves, they came full circle and essentially closed a gap in the field that their male counterparts could not. For they not only worked as the creators of the artwork, but they were themselves the object of creation - the pin-up. They were both the "commodifier" and the commodified. This paradoxical situation would almost suggest that the field of pin-up art was indeed, to a certain extent, a "natural" fit for women artists. While the subject matter was a great departure from illustrating women's magazines and children's books, women artists could draw upon themselves using mirrors, as in the case of Mozert, or photographs, as in the case of Ballantyne, while working within a field of art, illustration, that had more than half a century earlier been deemed a socially acceptable means of employment for women.

Choosing to use oneself as a model, however, results in a somewhat ambiguous state with regard to agency. On the one hand, women pin-up artists can be interpreted as having taken ownership over their bodies - controlling the way in which they were depicted and thus 
commercialized. The act of turning inwards, however, also relinquished a certain amount of control over oneself, as the idealized forms that they produced were indeed meant for consumption and voyeuristic purposes. As a result, it is difficult to say whether serving as one's own model is in fact an act of asserting agency over one's body and, more generally, over the female form, or whether, conversely, one is giving oneself over for objectificationobjectification carried out by those consuming the product and by the creator. Women pin-up artist who used themselves as models are thus left in an ambiguous and somewhat tenuous state when it comes to agency over their bodies. For it is not a "black and white" scenario, but rather one that is muddied - the complexity of which can indeed be seen and interpreted multiple ways. Ballantyne preferred to work in oil on canvas with many of her original pin-ups measuring $30 \times 24$ inches. Her women were never entirely nude. They always wore either some form of clothing or a towel because, Ballantyne stated, she did not "go in for dirty stuff" (Klinkenberg). Ballantyne's approach aligns with André Bazin’s 1946 analysis of the pin-up. He states, "The typical garment of the pin-up girl is the two-piece bathing suit-which coincides with the limitations authorized socially by fashion and modesty in recent years. At the same time, however, an infinite variety of suggestive degrees of undress - never exceeding some rigorously defined limits — show off to advantage the charms of the pin-up girl while pretending to hide them." Bazin continues, "the veils in which the pin-up girl is draped serve a dual purpose: they comply with the social censorship of a Protestant country which otherwise would not have allowed the pin-up girl to develop on an industrial and quasi-official scale; but at the same time make it possible to experiment with the censoring itself and use it as an additional form of sexual stimulus" (159). Bazin makes the point that the drapery of a pin-up — whether it be a bathing suit, a towel, or another form of clothing - is but a tantalizing veil. It serves to technically cover the 
woman's form thereby eliminating her status as a nude, while simultaneously enticing the viewer through its minimalism and testing the limits of censorship. Bazin contends that "the precise balance between the requirements of censorship and the maximum benefits one can derive from them without lapsing into an indecency too provocative for public opinion defines the existence of the pin-up girl, and clearly distinguishes her from the salaciously erotic or pornographic" (159). It was the fine and fluid line of early-twentieth-century propriety that pin-up artists had to walk in order to ensure that their work did not technically cross into the bounds of pornography or, as Ballantyne deemed it, "the dirty." This merging of innocence with the alluring defines the pin-up of the early- to mid-twentieth century.

Ballantyne advocated that in order to create a successful pin-up, one must make her "flirtatious." She explained, "You want the girl to look a little like your sister, or maybe your girlfriend, or just the girl next door. She's a nice girl, she's innocent, but maybe she got caught in an awkward situation that's a little sexy" (Klinkenberg). Ballantyne’s 1954 Just an Inking (Figure 4) is, like many pin-up narratives, seemingly innocent in nature yet highly suggestive with sexual overtones. The woman has been caught by surprise in the midst of writing a letter to, we presume, her significant other pictured on the desk just to her left. The ink from the pen and inkwell have spilled onto the woman's dress, which she lifts in an effort to assess the damage and halt the dripping. This otherwise innocent action is, in fact, the crux of the narrative, revealing to the viewer, and the man in the photograph, the woman's garters and stockingsleaving the consumer's imagination to wander. While the scene resounds with sexual impetus, it is also underpinned by release. For Ballantyne has positioned the inkwell immediately in front of the man's portrait, and as the ink pours over the desk from the cylindrical, arguably phallic, 
bottle onto the floor, the juxtaposition of the flowing ink and the young man's picture suggests sexual release- - supported by his exuberant smile.

In addition to her work as a pin-up artist, Ballantyne created what is arguably one of the most iconic images in American advertising history - the Coppertone Girl. After having asked several illustrators to submit sketches for the company's latest international ad campaign, in 1959 Coppertone suntan lotion announced that Ballantyne had won the commission. She received $\$ 2,500$ for the image of a blonde, pig-tailed little girl, whose cocker spaniel mischievously tugs at her bathing suit. Ballantyne modeled the girl after her three-year-old daughter, Cheri, because as Ballantyne stated, "she worked cheap and was convenient." The dog in turn was modeled after her neighbor's pet (Nelson B10). Unbeknownst to Ballantyne, her illustration would ultimately transcend generations and become synonymous with the Coppertone brand. Though when asked about the commission in 2004, Ballantyne stated that: "It was hardly the only art I ever produced, but that's what everybody remembers." She went on to described it as "Just another ad. Just another baby ad. Kind of boring" (Klinkenberg).

\section{Conclusion}

The sexual nature of pin-up art did not come without consequence. In 1943, the United States Post Office took formal action against Esquire, a popular men's magazine established just a decade earlier in the 1930s. The Post Office argued in court that Esquire's second-class mailing privileges should be revoked due to the "obscene, lewd, and lascivious character" of the pin-ups it featured (Preer). In an attempt to prove their case, postal authorities called a variety of witnesses to attest to the inappropriate nature of the pin-ups. Amongst those called was a bishop, who after being shown the magazine’s April 1943 Alberto Vargas pin-up, stated, "I wouldn’t 
care to exhibit this in my Sunday School class" ("Bishop Hughes"). Despite their best efforts, the Supreme Court ultimately ruled that the US Post Office did not, in this instance, have the authority to revoke Esquire magazine's second-class mailing permit on the basis of the pin-ups. This case is important because it highlights the conflicting attitudes towards pin-up art during the first half of the twentieth century and also that these illustrations were hotly debated points of contention. A fact that, arguably, further complicated a woman's role as a pin-up artist when one considers the tenets of a domestic ideology.

The complicated history of women working as pin-up artists during the first half of the twentieth century remains overlooked. Although women had indeed established themselves firmly as professional illustrators by the turn of the twentieth century, the transition to subject matter of a blatantly sexual nature created for male consumption did not easily align with popular notions regarding women's work. Nevertheless, several artists, including, but not limited to, Pearl Frush, Zoë Mozert, and Joyce Ballantyne, not only succeeded but excelled in the field of pin-up art. They did so by utilizing their highly-honed skills as illustrators, coupled with their understanding of male consumer print-culture. Standing upon the shoulders of those female illustrators who came before them, they pushed the boundaries of the field of illustration for women — asserting their agency over a genre understood to be masculine - helping to redefine the parameters of women's professional pursuits. 


\section{Works Cited}

Armstrong, Regina. "Representative American Women Illustrators: The Character Workers." The Critic, vol. 37, 1900, pp. 43-54.

- - - "Representative American Women Illustrators: The Child Interpreters." The Critic, vol. 36, 1900, pp. 417-29.

Bazin, André. "Entomology of the Pin-Up Girl.” What is Cinema? Vol.II, U of California P, 2005, pp. 158-62.

“Bishop Hughes 'Meets' a Varga Girl.” Washington Times-Herald, 6 Nov. 1943, reprinted in Jean Preer, "Esquire v. Walker: The Postmaster General and 'The Magazine for Men,"” Prologue Magazine, vol. 23, no. 1, 1990, www.archives.gov/publications/prologue/1990/spring/esquire-v-walker-1.html. Accessed 26 Feb. 2016.

“Bitten Artist Will Sue All Except Skunk.” Los Angeles Times, 21 Sept. 1948, p. 20.

Buszek, Maria Elena. Pin-up Grrrls: Feminism, Sexuality, Popular Culture. Duke UP, 2006.

“Calendar Artist Mozert Uses Herself as Model.” Los Angeles Times, 26 Feb. 1945, p. A1.

“Calendar Girl Artist Mozert Wins Divorce.” Los Angeles Times, 24 March 1945, p. 3.

Callen, Anthea. Angel in the Studio: Women in the Arts and Crafts Movement 1870-1914. Astragal Books, 1979.

Collins, Max Allan. For the Boys: The Racy Pin-Ups of World War II. Metro Books, 2000.

Elzea, Roland. The Golden Age of American Illustration 1880-1914. The Wilmington Society of the Fine Arts, 1972.

“Flower Festival Queen Selected.” Los Angeles Times, 30 Mar. 1947, p. 16.

Goodman, Helen. "Women Illustrators of the Golden Age of American Illustration.” Woman's 
Art Journal, vol. 8, 1987, pp. 13-22.

Hess, Thomas B. "Pinup and Icon.” Woman as Sex Object: Studies in Erotic Art, 1730-1970, edited by Thomas B. Hess and Linda Nochlin, Newsweek, 1972, pp. 222-37.

Irwin, Cheri Brand. "The Artist Behind the Coppertone Girl Ad.” Interview with Madeleine Brand, Remembrances, National Public Radio, 18 May 2006, www.npr.org/templates/transcript/transcript.php?storyId=5415067. Accessed $21 \mathrm{Jun}$. 2017.

Kessler-Harris, Alice. Out to Work: A History of Wage-Earning Women in the United States. Oxford UP, 2003.

Klinkenberg, Jeff. "Real Florida: Red-Faced with the Coppertone Girl.” St. Petersburg Times, 5 Sept. 2004, www.sptimes.com/2004/09/05/Floridian/Real_Florida_Red_fac.shtml. . Accessed 24 Oct. 2017.

Martignette, Charles G., and Louis K. Meisel. The Great American Pin-Up. Taschen, 1996. May, Martha. Women's Roles in Twentieth-Century America. Greenwood Press, 2009.

Meyerowitz, Joanne. "Women, Cheesecake, and Borderline Material: Responses to Girlie Pictures in the Mid-Twentieth-Century U.S.” Journal of Women's History, vol. 8, no. 3, 1996, pp. 9-35.

“Model’s Favorite." Chicago Daily Tribune, 9 Mar. 1938, p. 4.

Nead, Lynda. The Female Nude: Art, Obscenity, and Sexuality. Routledge, 1992.

Nelson, Valerie J. “Obituary: Joyce Ballantyne Brand, 88; Commercial Artist Created Iconic Coppertone Image.” Los Angeles Times, 19 May 2006, p. B10.

Neuhaus, Jessamyn. “The Way to a Man’s Heart: Gender Roles, Domestic Ideology, and Cookbooks in the 1950s." Journal of Social History, vol. 32, no. 3, 1999, pp. 529- 
55.

Palm, Regina. "Feminine by Design: Re-Engendering Mural Painting at the fin de siècle."

Women's History Review, vol. 23, no. 1, 2014, pp. 82-98.

Penny, Virginia. The Employments of Women: A Cyclopaedia of Woman's Work. Walker, Wise, \& Company, 1863.

Preer, Jean. "Esquire v. Walker: The Postmaster General and 'The Magazine for Men'.”

Prologue Magazine, vol. 23, no. 1, 1990,

www.archives.gov/publications/prologue/1990/spring/esquire-v-walker-1.html. Accessed

26 Feb. 2016

Prieto, Laura R. At Home in the Studio: The Professionalization of Women Artists in America.

Harvard UP, 2001.

Sawaya, Francesca. Modern Women: Domesticity, Professionalism, and American Writing, 1890-1950. U of Philadelphia P, 2004.

Shuttleworth, Sally, et al. "Women, Science and Culture: Science in the Nineteenth-Century

Periodical.” Women: A Cultural Review, vol. 12, no. 1, 2001, pp. 57-70.

\footnotetext{
${ }^{1}$ For a discussion of the shifts American women experienced in relation to gender roles during the first half of the twentieth century, see Sawaya, Modern Women; May, Women's Roles; and Kessler-Harris, Out to Work.

${ }^{2}$ For a discussion of the way in which women artists negotiated the gender politics of mural painting at the turn of the twentieth century, see Palm, "Feminine by Design."

${ }^{3}$ Prior to the 1880 s the cost of many magazines in America ranged from twenty-five to thirtyfive cents an issue. By 1893, however, the newly launched magazine McClure's cost only fifteen cents (Elzea 8).

${ }^{4}$ For a critical discussion of the female body in art, see Nead, Female Nude.

${ }^{5}$ Collins also discusses Frush's choice of medium and the general size of her originals (11).

${ }^{6}$ Buszek's Pin-Up Grrrls discusses the pin-up and its various permutations during World War II in chapter 5, "New Frontiers: Sex, Women, and World War II."

${ }^{7}$ In addition to being featured in newspaper articles because of her work as an artist, due to her celebrity, Zoë Mozert's personal life also served as fuel for local papers. For example, on March 24, 1945, Mozert's divorce from newspaperman Don J. Kirkley was featured in the Los Angeles
} 
Times under the title "Calendar Girl Artist Mozert Wins Divorce," accompanied by a photo of Mozert. Additionally, on September 21, 1948, an article titled "Bitten Artist Will Sue All Except Skunk" was also featured in the Los Angeles Times. The article described how Mozert purportedly had been bitten by a skunk at a pet shop, which resulted her inability to work and fulfill contractual obligations for several weeks. 


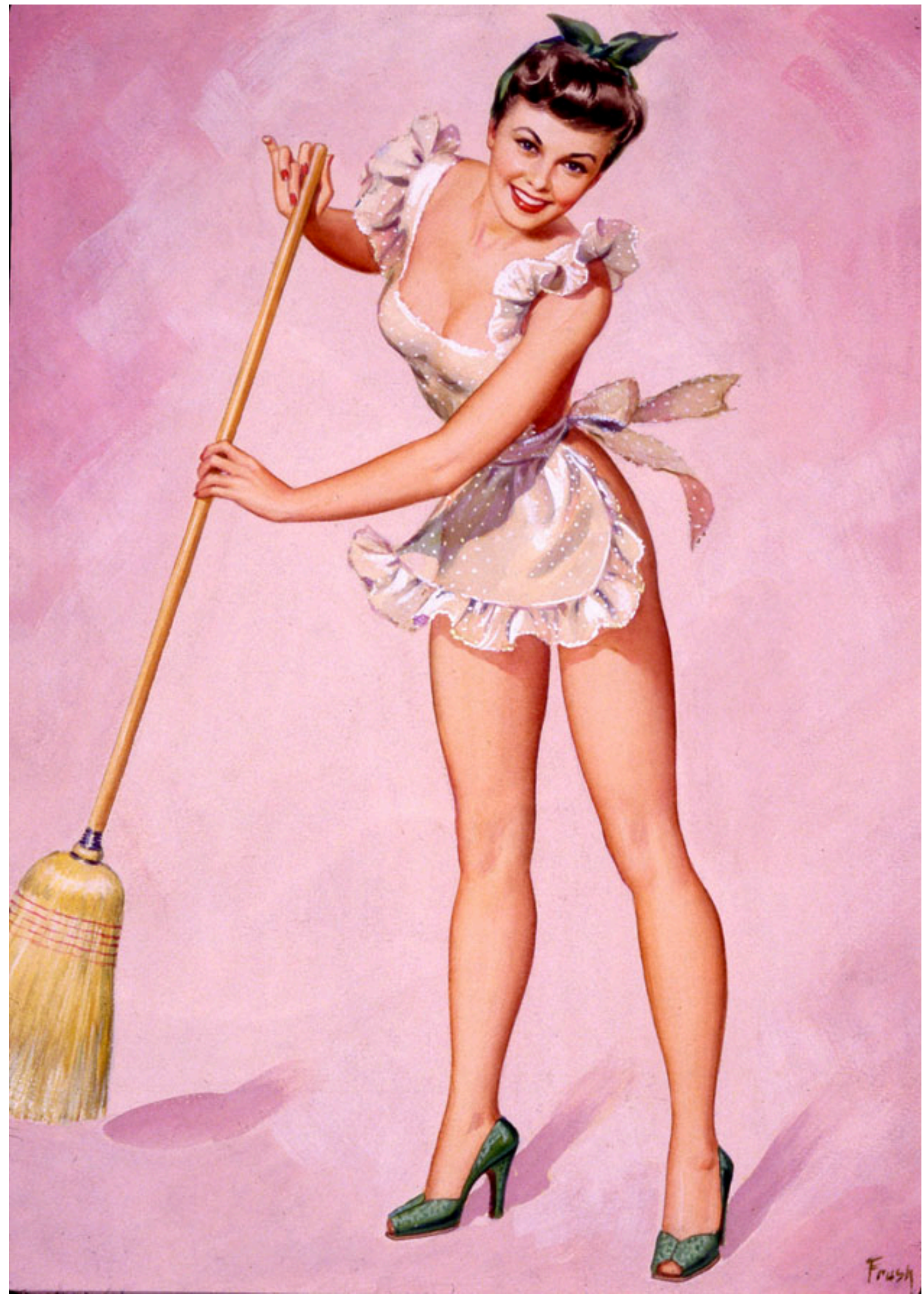

FIGURE 1. Pearl Frush, Always Ready, 1945. 


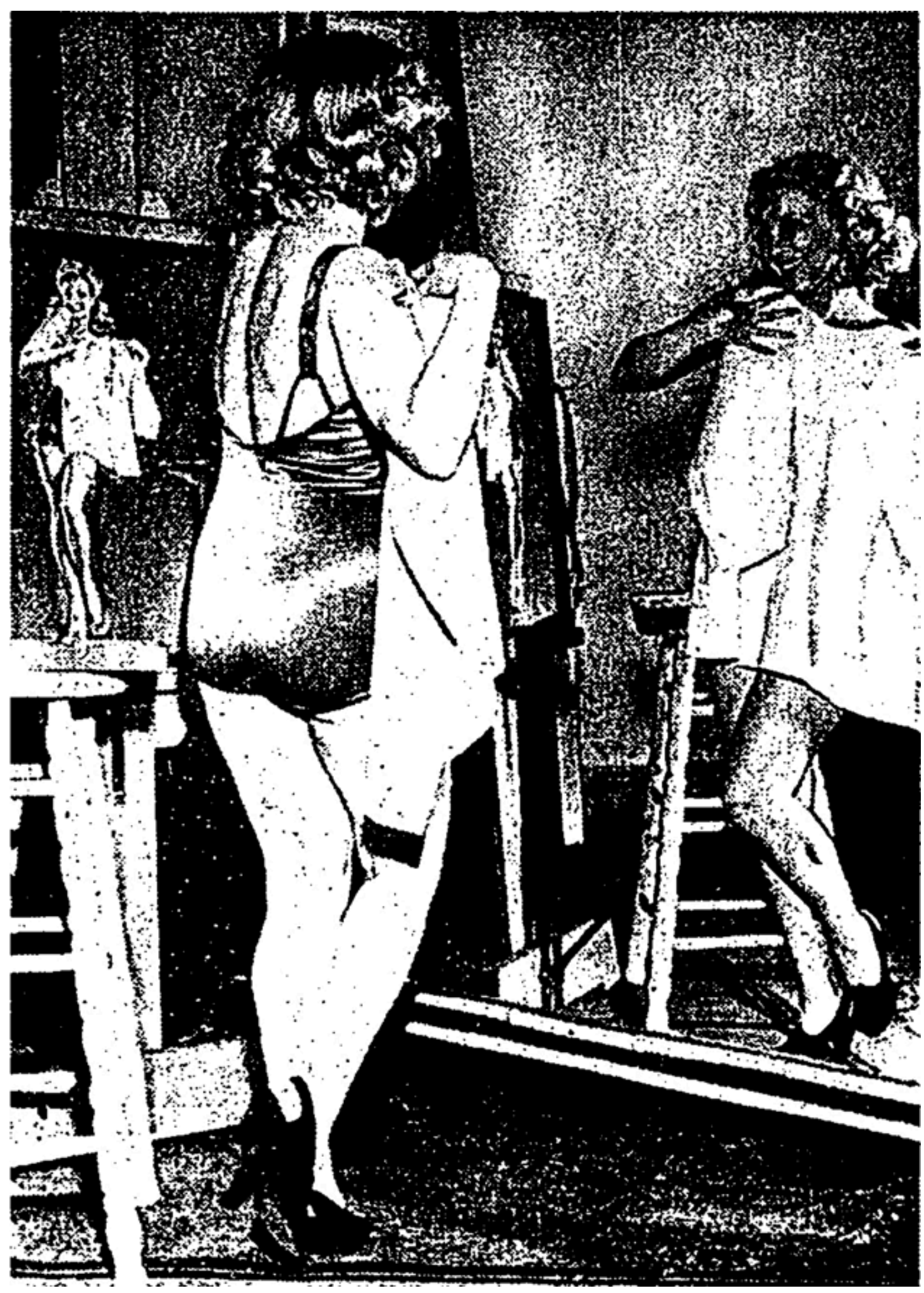

FIGURE 2. 'Calendar Artist Mozert Uses Herself as Model.' Copyright (C1945. Los Angeles Times. Used with Permission. 


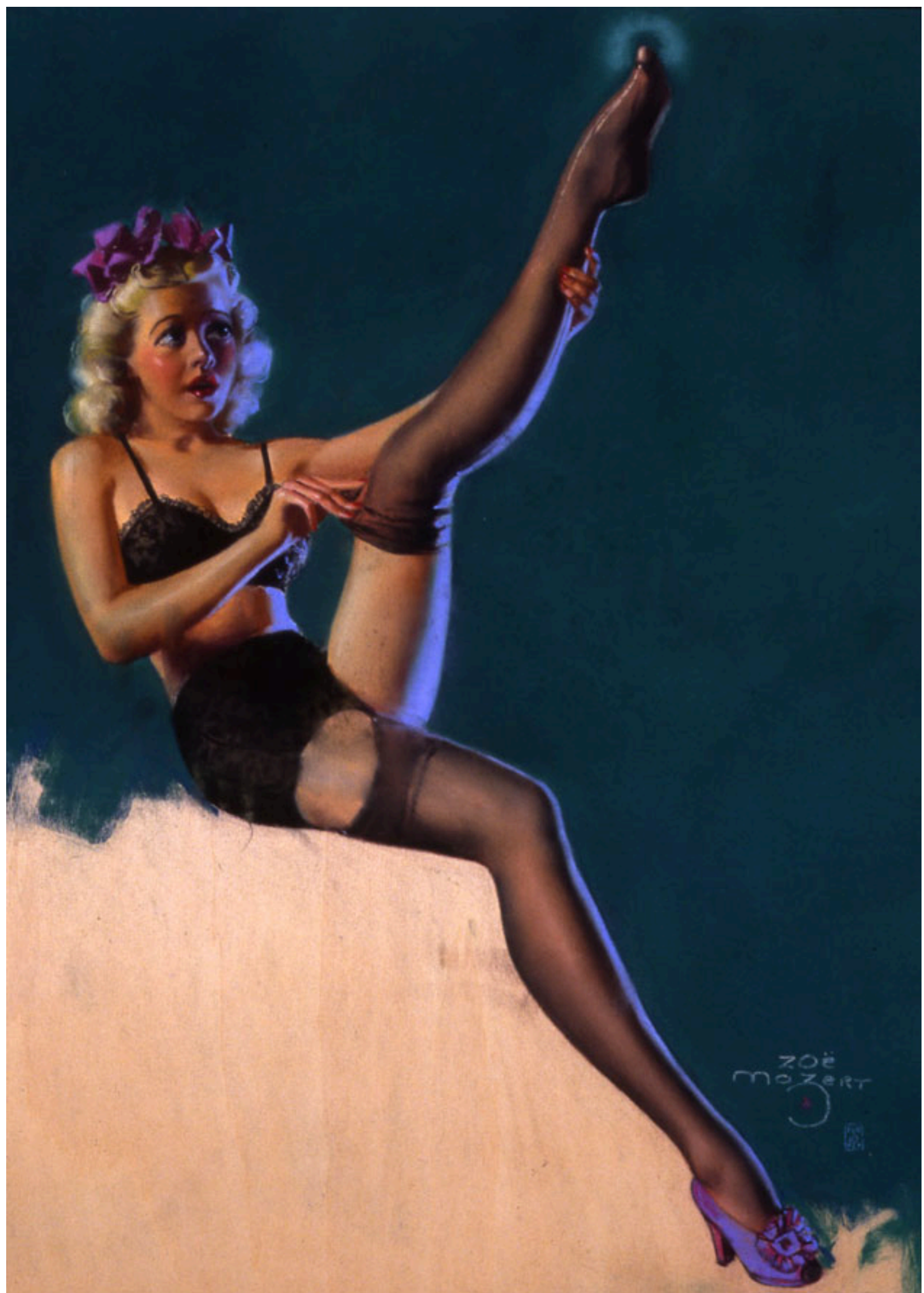

FIGURE 3. Zoë Mozert, A Run on Sugar, 1948. 


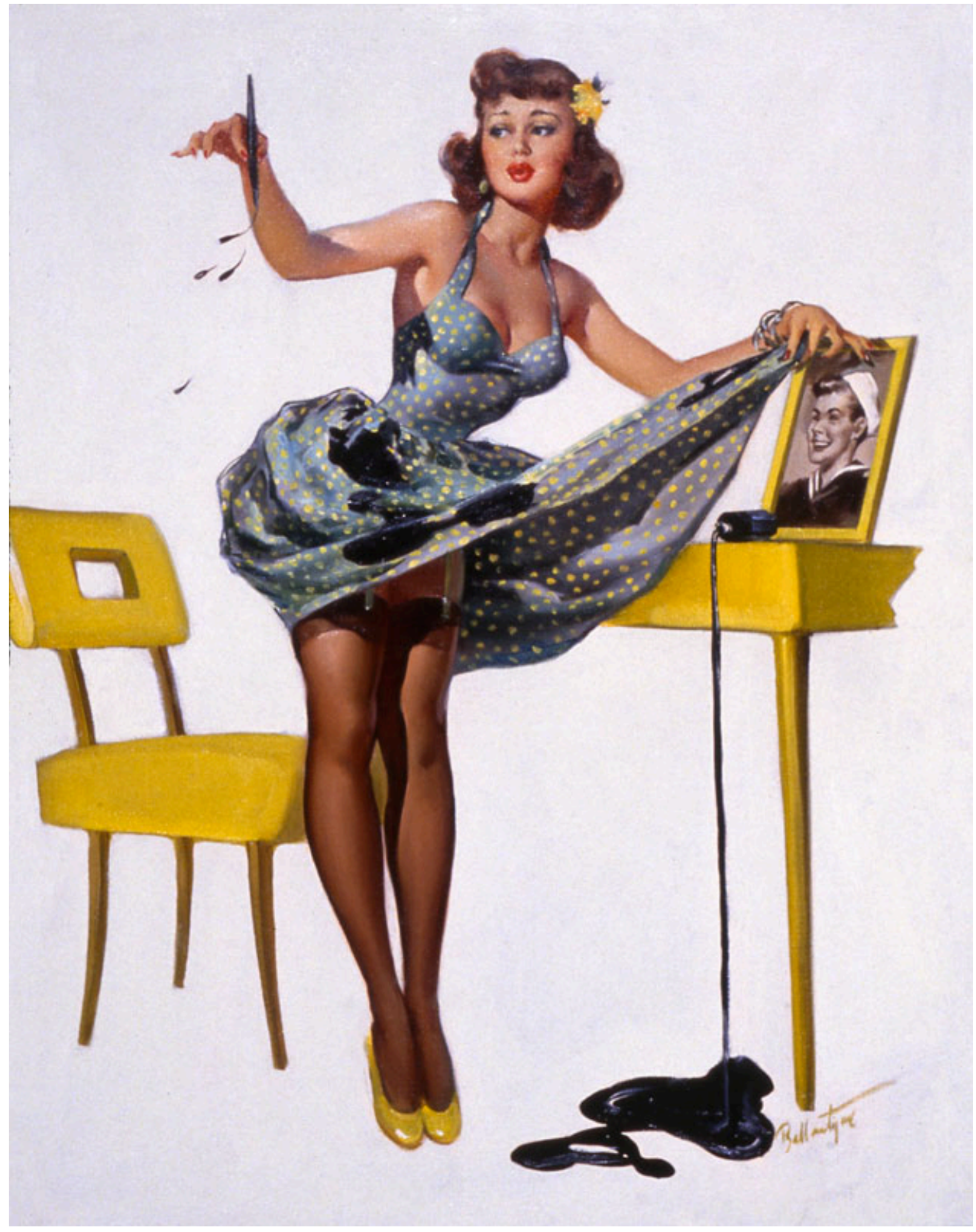

FIGURE 4. Joyce Ballantyne, Just an Inking, 1954. 